\title{
Synthesis, Characterization and Docking Studies of 4, 4'-Diaminotriphenylmethanes (DATPMs)
}

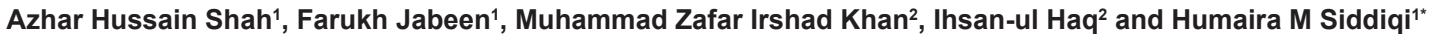

${ }^{1}$ Department of Chemistry, Quaid-I-Azam University, Islamabad, Pakistan

${ }^{2}$ Department of Pharmacy, Faculty of Biological Sciences, Quaid-I-Azam University, Islamabad, Pakistan

\begin{abstract}
DATPMs were synthesized by the acid-catalysed Baeyer condensation of 4-substituted benzaldehydes and aniline in good yields. The materials were purified by column chromatography and characterized by FTIR, ${ }^{1} \mathrm{H}-{ }^{13} \mathrm{CNMR}$ and elemental analysis. The optimized ligands were docked with the IKKa, (PDB code: 3BRT) using the MOE-Dock module and are found to obey Lipinski's Ro5 cut-off limits. The computational results revealed that the DATPMs, like other derivatives of TPM, could be potential anticancer drugs. Moderate protein kinase inhibitory activity was exhibited by samples 2 and 3 by displaying inhibition bald zone of 10 and $9 \mathrm{~mm}$ respectively against the Streptomyces 85E strain.
\end{abstract}

Keywords: Baeyer condensation; 4, 4'-Diaminotriphenylmethanes (DATPMs); Triphenylmethane motif; Computational studies; Anticancer agents

\section{Introduction}

Cancer has been emerged as leading cause of the deaths claiming around $13 \%$ of the all reported death round the globe. Though the chemotheraptic methods has progressed a lot in the recent years yet there is always a need of developing new highly potent anticancer drugs with less toxicity and high specificity [1]. In the recent years, triarymethyl motif has been identified as anticancer agent in the mice cells. It has been shown that the triphenylmethyl containing compounds cause the death of melanoma cells in mice cells with reduced toxicity to normal cells of human bone marrow even high doses were tolerated by the mice cells [2]. Several new compounds with triarylmethyl groups have been designed and synthesized successfully. Particularly, clotrimazole, an antifungal agent with imidazole and triarylmethyl groups, inhibits the growth of cancer cells in culture [3] as well as in cancerous mouse models $[3,4]$. The mode of action of this triarylmethyl motif underlies in its ability to inhibit translation mediated by depletion of intracellular $\mathrm{Ca}^{+2}$ concentrations and also by inhibition of glycolysis by prompting the detachment of mitochondrial bound hexokinase [3,5]. 3,3-diaryl1,3-dihyroindoles, an indole modified triarylmethanes, possess antiproliferative activity against cancer cell lines in cell culture $[6,7]$. Previously, Triarylmethanes (TAMs) have been found to be potent against digestive and intestinal parasitic worms and other protozoa like filariae, trichomonads, and trypanosomes [8]. Arthur et al. [9] prepared some triarylmethane derivaties with hydroxyl groups active against hyaluronidase and polyarthriltis moreover phenol derivatives of TAM have been known to reveal antioxidant properties, antitumor activity, and inhibitory activity toward histidine protein kinase.

Molecular docking techniques are powerful tools in the field of drug designing $[10,11]$. These methods enable us to study how the target macromolecule responds to the ligand when placed in the noncovalent fashion. DOCK [12], Autodock [13], and Molecular Operating Environment (MOE) [14] are the extensively used computational programs to study the ligand-target interactions. Thus, screening of the non-active drugs can be done before performing experiments to minimize the cost and time for the development of the potential drugs [15].

4, 4'-Diaminotriphenylmethanes (DATPMs) are di-amino derivatives of (TPMs). DATPMs have been extensively used as dyes, precursors in polyimide synthesis and other high performance polymers and as corrosion inhibitor of copper [16]. They have been employed as antifungal agents in fish hatcheries [17] and also in hostguest chemistry [18] of crown ethers. The most celebrated method to synthesize the DATPMs is Baeyer's condensation where aniline is treated with benzaldehyde in presence of an acid [19]. Copious methods have been reported so far for the synthesis of these interesting materials with various catalysts namely dry $\mathrm{HCl}$ [20], acid Zeolites [21], p-Toluenesulphonic acid [22], 12-Tungstophosphoric acids [19] and microwave conditions [16]. Though DATPMs contain TAM ring so it could be interesting to know about their biological and pharmaceutical properties especially anticancer activity for which triarylmethyl motif is renowned but the materials are not being tested for anticancer activities so far. The present work is all about synthesis, structural characterization, computational studies and wet lab analysis of DATPMs. We have successfully synthesized five DATPMs with different functional groups at para position of the aromatic ring using aniline hydrochloride as a proton donor catalyst and para-substituted benzaldehydes. The docking studies of the all synthesized DATPMs revealed that, like other triarylmethyl derivaties, they could be promising candidates as anticancer agents.

Protein kinases modifies other proteins by adding phosphate group to them chemically i.e., they cause the phosphorylation of the proteins. Phosphorylation cause a change in the target proteins by altering enzyme activity, cellular location or association with other proteins [23]. Most protein kinases proceed on serine and threonine while some act on tyrosine and some act on all the three [24]. Deregulated phosphorylation by protein kinases is one of the persistent cause of disease specially cancer because it cause change in genetic signaling in tumorigenesis. So the agents that cause the inhibition of protein kinases could be encouraging mark for cancer treatment [25]. In the present

*Corresponding author: Humaira M Siddiqi, Department of Chemistry, QuaidI-Azam University, Islamabad, 45320, Pakistan, Tel: +925190642148; E-mail: humairas@qau.edu.pk

Received July 02, 2017; Accepted July 17, 2017; Published July 25, 2017

Citation: Shah AH, Jabeen F, Khan MZI, Haq I, Siddiqi HM (2017) Synthesis, Characterization and Docking Studies of 4, 4'-Diaminotriphenylmethanes (DATPMs). Med Chem (Los Angeles) 7: 213-217. doi: 10.4172/2161-0444.1000459

Copyright: ( 2017 Shah $\mathrm{AH}$, et al. This is an open-access article distributed under the terms of the Creative Commons Attribution License, which permits unrestricted use, distribution, and reproduction in any medium, provided the original author and source are credited. 
study Streptomyces $85 \mathrm{E}$ strain was used for the assay to analyze the possible inhibitors of protein kinase. Protein kinases are involved in the aerial hyphae formation of Streptomyces, so the extract that will inhibit the protein kinases, there will be no hyphae formation and bald zone will appear which will be perspective for their kinase inhibitory activity.

\section{Experimental}

\section{Materials}

4-Hydroxybenzaldehyde (98\%, Aldrich), 4-Nitrobenzaldehyde (98\%, Aldrich), 4-Methoxybenzaldehyde (98\%, Aldrich), benzaldehyde (Reagent plus, $\geq 99 \%$ ), 4-chlorobenzaldehyde (97\%, Aldrich) and Aniline (extra pure 99.5\%, Acros Organic) were used as received. All reactions were carried out in anhydrous conditions and under static pressure of nitrogen. All the reactions were monitored through thin layer chromatography using pre-coated silica gel glass plates (layer thickness $0.25 \mathrm{~mm}, \mathrm{HF}-254$, E. Merck). Products were purified by Column chromatography on E. Merck silica gel (0.063-0.040 mm).

\section{Characterization}

Infra-red measurements were obtained using an ATR-FTIR spectrometer (Perkin Elmer). Each sample was measured over 64 scans with resolution of $4 \mathrm{~cm}^{-1}$ in the range of $600-4000 \mathrm{~cm}^{-1}$.

${ }^{1} \mathrm{H}$ and Carbon $\left({ }^{13} \mathrm{C}\right)$ NMR spectra were carried out by the 400 $\mathrm{MHz}$ Bruker DPX-400 spectrometers (Provided by Cambridge Isotope Laboratories) using solvent peak as reference. The NMR samples were run in DMSO- $d_{6}$ solvent. DMSO- $d_{6}$ was dried on molecular sieves before using it for analysis.

Microanalysis, total carbon, nitrogen and hydrogen were determined by a commercial elemental analyzer running under computer control. Samples were precisely weighed on Mettler UMT2 microbalance into light weight tin capsules and then dropped into combustion tube of the elemental analyser (Carlo-Erba EA 1108) through which a constant stream of helium is maintained.

\section{General procedure for synthesis of diamines}

A mixture of aldehyde $(0.041 \mathrm{~mol})$, aniline $(\mathrm{g}, 0.1025 \mathrm{~mol})$ and aniline hydrochloride $(0.53 \mathrm{~g}, 0.004 \mathrm{~mol})$ was charged and stirred at reflux at $120^{\circ} \mathrm{C}$ under a nitrogen flow for $3 \mathrm{~h}$. The progress of reaction was monitored by TLC in n-hexane: ethyl acetate (1:1) solvent system. After the completion of the reaction, the mixture was cooled and 100 $\mathrm{mL}$ ethanol was added. The entire mixture was then heated to $80^{\circ} \mathrm{C}$ to dissolve the lumpy material, cooled, and held overnight. Crystals precipitated out, filtered off, and recrystallized in ethanol/ benzene. Crude crystalline product was isolated and dried. The product was washed with ethanol a few times to remove the aniline residue and was again washed with water to remove the salts. Finally, the pure product was obtained after column chromatography using $30 \%$ ethylacetate in n-hexane as an eluent.
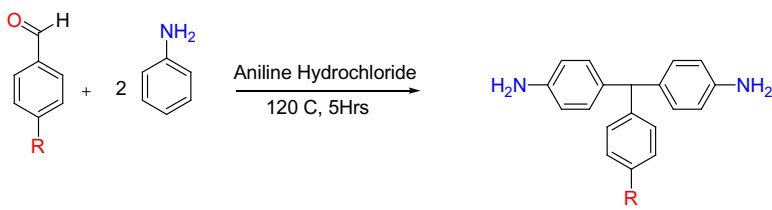

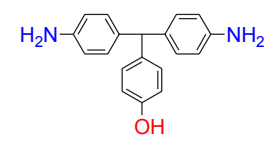

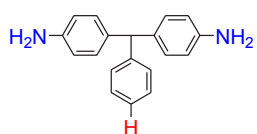

2

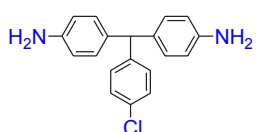

3

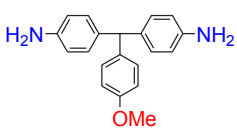

4

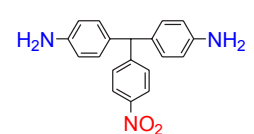

Synthesis of 4-(bis(4-aminophenyl)methyl)phenol (1): Diamine was prepared according to the general procedure using 4-Hydroxybenzaldehyde ( $0.041 \mathrm{~mol}, 5.104 \mathrm{~g})$, Aniline (9.58 g, 0.1025 $\mathrm{mol}$ ) and aniline hydrochloride ( $0.53 \mathrm{~g}, 0.004 \mathrm{~mol})$. Yield $43 \%, \mathrm{R}_{\mathrm{f}}=0.27$ in Ethyl acetate: $\mathrm{n}$-Hexane, $(1: 1), \mathrm{mp}=206-207^{\circ} \mathrm{C}$. FTIR: $\bar{v}\left(\mathrm{~cm}^{-1}\right): 3440$ $3340(\mathrm{~N}-\mathrm{H}), 3500-3300(\mathrm{O}-\mathrm{H}), 2860\left(\mathrm{C}_{\mathrm{sp} 3}-\mathrm{H}\right), 1239(\mathrm{C}-\mathrm{O}), 1610(\mathrm{C}=\mathrm{C}$ aromatic). Elemental Analysis for $\mathrm{C}_{19} \mathrm{H}_{18} \mathrm{~N}_{2} \mathrm{O}$ in wt\% (Calcd, found) $\mathrm{C}=(78.60,78.44), \mathrm{H}=(6.25,6.35), \mathrm{N}=(9.65,9.7) .{ }^{1} \mathrm{HNMR}(400 \mathrm{MHz}$, DMSO- $d$, ppm): $\delta, 4.84\left(\mathrm{~s}, 4 \mathrm{H}, 2 \mathrm{NH}_{2}\right), 5.05(1 \mathrm{H}, \mathrm{CH}), 6.45-6.85(4 \mathrm{dd}$, $12 \mathrm{H}$, Aromatic protons), $9.12(1 \mathrm{H}, \mathrm{OH}$, phenolic proton $) .{ }^{13} \mathrm{CNMR}$ (100 MHz, DMSO- $d_{6}$, ppm): 54.2, 114.1, 115.1, 129.7, 130.1, 132.9, 136.4, 146.8, 155.6.

Synthesis of 4-((4-aminophenyl)(phenyl)methyl)benzenamine (2): Diamine was prepared according to the general procedure using benzaldehyde ( $0.041 \mathrm{~mol}, 4.39 \mathrm{~g})$, Aniline $(9.58 \mathrm{~g}, 0.1025 \mathrm{~mol})$ and aniline hydrochloride $(0.53 \mathrm{~g}, 0.004 \mathrm{~mol})$. Yield $47 \%, \mathrm{Rf}=0.37$ in Ethyl acetate: $n$-Hexane, (1:1), mp=92-94 ${ }^{\circ} \mathrm{C}$. Elemental Analysis for $\mathrm{C}_{19} \mathrm{H}_{18} \mathrm{~N}_{2}$ in $\mathrm{wt} \%$ (Calcd, found) $\mathrm{C}=(83.18,83.3), \mathrm{H}=(6.61,6.90), \mathrm{N}=(10.21$, 9.97). FTIR: $\bar{v}\left(\mathrm{~cm}^{-1}\right)$ : 3449, $3359(\mathrm{~N}-\mathrm{H}), 2929,2834\left(\mathrm{C}_{\mathrm{sp} 3}-\mathrm{H}\right), 1617$ ( $\mathrm{C}=\mathrm{C}$ aromatic). $1 \mathrm{H}$ NMR (400 MHz, DMSO- $d_{6}$, in $\delta(\mathrm{ppm}): 4.86(\mathrm{~s}$, $\left.4 \mathrm{H}, 2 \mathrm{NH}_{2}\right), 5.17(1 \mathrm{H}, \mathrm{CH}), 6.46-6.26\left(\mathrm{M}, 13 \mathrm{H}\right.$, Aromatic protons). ${ }^{13} \mathrm{C}$ NMR: (100 MHz, DMSO- $d$, ppm): 55.0, 114.2, 126.1, 128.4, 129.3, $129.8,132.3,146.2,147.0$.

Synthesis of 4-((4-aminophenyl)(4-chlorophenyl)methyl) benzenamine (3): Diamine was prepared according to the general procedure using 4-Chlorobenzaldehyde $(0.041 \mathrm{~mol}, 5.94 \mathrm{~g})$, Aniline (9.58 g, $0.1025 \mathrm{~mol})$ and aniline hydrochloride $(0.53 \mathrm{~g}, 0.004 \mathrm{~mol})$. Yield $55 \%, \mathrm{Rf}=0.31$ in Ethyl acetate: $\mathrm{n}$-Hexane, $(1: 1), \mathrm{mp}=109-111^{\circ} \mathrm{C}$. Elemental Analysis for $\mathrm{C}_{19} \mathrm{H}_{17} \mathrm{~N}_{2} \mathrm{Cl}$ in wt\% (Calcd, found) $\mathrm{C}=(73.9$, 73.75), $\mathrm{H}=(5.55,6.71), \mathrm{N}=(9.07,9.95)$. FTIR: $\overline{\mathrm{v}}\left(\mathrm{cm}^{-1}\right): 3428,3348(\mathrm{~N}-$ $\mathrm{H}), 2962,2857\left(\mathrm{C}_{\mathrm{sp} 3}-\mathrm{H}\right), 1618(\mathrm{C}=\mathrm{C}$ aromatic $) .{ }^{1} \mathrm{HNMR}(400 \mathrm{MHz}$, DMSO- $d, \mathrm{ppm}): \delta, 4.95\left(\mathrm{~s}, 4 \mathrm{H}, 2 \mathrm{NH}_{2}\right), 5.23(1 \mathrm{H}, \mathrm{CH}), 6.52-7.36(4 \mathrm{dd}$, $12 \mathrm{H}$, Aromatic protons). ${ }^{13} \mathrm{CNMR}\left(200 \mathrm{MHz}, \mathrm{DMSO}-d_{6}, \mathrm{ppm}\right): 54.2$, $114.2,128.4,129.7,130.7,131.1,131.75,145.3,147.2$.

Synthesis of 4-((4-aminophenyl)(4-methoxyphenyl)methyl) benzenamine (4): Diamine was prepared according to the general procedure using 4-Methoxybenzaldehyde $(0.041 \mathrm{~mol}, 5.57 \mathrm{~g})$, Aniline $(9.58 \mathrm{~g}, 0.1025 \mathrm{~mol})$ and aniline hydrochloride $(0.53 \mathrm{~g}, 0.004 \mathrm{~mol})$. Yield $47 \%, \mathrm{R}_{\mathrm{f}}=0.32$ in Ethyl acetate: $\mathrm{n}$-Hexane, $(1: 1), \mathrm{mp}=128-130^{\circ} \mathrm{C}$. Elemental Analysis for $\mathrm{C}_{20} \mathrm{H}_{20} \mathrm{~N}_{2} \mathrm{O}$ in wt\% (Calcd, found) $\mathrm{C}=(78.92$, 78.62), $\mathrm{H}=(6.62,6.45), \mathrm{N}=(9.2,8.88)$. FTIR: $\bar{v}\left(\mathrm{~cm}^{-1}\right): 3406,3331(\mathrm{~N}-$ $\mathrm{H}), 2959,2836\left(\mathrm{C}_{\mathrm{sp} 3}-\mathrm{H}\right), 1605$ (C=C aromatic), 1240 (C-O). ${ }^{1} \mathrm{H}$ NMR: (400 MHz, DMSO- $d$, ppm): $3.70\left(\mathrm{~s}, 3 \mathrm{H}, \mathrm{OCH}_{3}\right), 4.85$ (s, $\left.4 \mathrm{H}, 2 \mathrm{NH}_{2}\right)$, $5.11(1 \mathrm{H}, \mathrm{CH}), 6.45-6.97$ (4dd, $12 \mathrm{H}$, Aromatic protons). ${ }^{13} \mathrm{C}$ NMR: $(100$ $\left.\mathrm{MHz}, \mathrm{DMSO}-d_{6}, \mathrm{ppm}\right): 54.2,55.4,113.8,114.1,129.7,130.2,132.7$, $138.2,147.0,157.6$.

Synthesis of 4-((4-aminophenyl)(4-Nitrophenyl)methyl) 
benzenamine (5): Diamine was prepared according to the general procedure using 4-Nitrobenzaldehyde $(0.041 \mathrm{~mol}, 6.196 \mathrm{~g})$, Aniline $(9.58 \mathrm{~g}, 0.1025 \mathrm{~mol})$ and aniline hydrochloride $(0.53 \mathrm{~g}, 0.004 \mathrm{~mol})$. Yield $47 \%, \mathrm{Rf}=0.30$ in Ethyl acetate: $\mathrm{n}-\mathrm{Hexane},(1: 1), \mathrm{mp}=125-127^{\circ} \mathrm{C}$. Elemental Analysis for $\mathrm{C}_{19} \mathrm{H}_{17} \mathrm{~N}_{3} \mathrm{O}_{2}$ in wt\% (Calcd, found) $\mathrm{C}=(71.46$, 70.96), $\mathrm{H}=(5.37,5.50), \mathrm{N}=(13.16,13.12)$. FTIR: $\bar{v}\left(\mathrm{~cm}^{-1}\right): 3420-3355(\mathrm{~N}-$ $\mathrm{H}), 2932,2825\left(\mathrm{C}_{\mathrm{sp} 3}-\mathrm{H}\right), 1609(\mathrm{C}=\mathrm{C}$ aromatic $),\left(\mathrm{NO}_{2}\right.$ group). ${ }^{1} \mathrm{H}$ NMR: (400 MHz, DMSO-d, ppm): $4.57\left(\mathrm{~s}, 4 \mathrm{H}, 2 \mathrm{NH}_{2}\right), 5.44(1 \mathrm{H}, \mathrm{CH}), 6.62-$ 8.15 (4dd, $12 \mathrm{H}$, Aromatic protons). ${ }^{13} \mathrm{C}$ NMR: (100 MHz, DMSO- $d_{6}$, ppm): 55.0, 114.3, 123.1, 129.8, 130.2, 131.6, 146.9, 154.2.

\section{Molecular docking}

Preparation of receptor: Molecular Operating Environment (MOE 2014) by Chemical Computing Group (CCG) was used for the current studies [26]. The protein preparation steps involved 3D protonation, energy minimization, and active site identification. The crystal structure of the IKKa was retrieved from a protein data bank [27]. The co-crystallized bound water molecules were stripped off from the crystal structure. Receptor was energy minimized and 3-D protonated by using the structure preparation module of MOE. Since 3BRT devoid of any co-crystallized ligand, therefore, active site was identified by using the site finder module offered by MOE program. In order to visualize the binding pocket, alpha spheres were created followed by the generation of dummy atoms on the centers of these spheres. The pocket was found to be a deep cavity lined with the amino acid residues including both hydrophobic and hydrophilic amino acids. The protein IKKa, (PDB code: 3BRT) comprises of four chains.

Preparation of ligands: The ligand files for molecular docking studies were prepared in Molecular Operating Environment (MOE2014). 3D Structure of ligand molecules by making use of builder module of MOE program was drawn. Ligand preparation was comprehensive collection of tools, inclusive of $3 \mathrm{D}$ protonation and energy minimization by using MMFF94 with 0.001 iteration criterion [28]. This exercise generated lower energy, stable, accurate and minimized 3D models. The optimized geometries were saved in molecular data base file for further studies.

Molecular docking studies: The optimized ligands were docked with the IKKa, (PDB code: 3BRT) using the MOE-Dock module. For docking simulations, default MOE docking parameters such as triangle matcher algorithm with two rescoring functions such as London dG and
GBVI/WSA dG were utilized to generate 30 poses of each compound. As a result of docking run mdb output files were generated enclosing all docking results with scoring and multiple conformations of ligands. All the docked conformations were analyzed and the best scored pose for each compound was selected for further studies of interaction evaluation. The $2 \mathrm{D}$ ligand-protein interactions were visualized using the MOE ligand interaction function and recorded in Table 1.

Protein kinase inhibition assay: Streptomyces $85 \mathrm{E}$ strain was used for the protein kinase inhibition assay, in which hyphae formation was detected to explore the efficacy (potency) of the sample [25] Refreshed culture of Streptomyces was used for spreading spores and lawn formation (mycelia fragments) on sterile plates containing minimal ISP4 medium. About $20 \mu \mathrm{g}$ of final concentration of sample ( $2 \mu \mathrm{l} \mathrm{from} 10 \mathrm{mg} / \mathrm{ml}$ of DMSO) was loaded on sterile $6 \mathrm{~mm}$ filter paper discs, which were placed immediately right on the surface of the plate implanted with Streptomyces 85E. Surfactin loaded on disc was used as positive control while DMSO was used as negative control. After loading of samples, plates were kept for incubation at $30^{\circ} \mathrm{C}$ for $72 \mathrm{~h}$ (time required for hyphae formation in Streptomyces 85E). The results were noted by measuring the bald zone of inhibition around the discs on which sample were loaded. The assay was run three times. The samples showing inhibition zone of $>12 \mathrm{~mm}$ were significant and $\mathrm{IC}_{50}$ of such samples were found at lower concentration, the lowest concentration at which it inhibits the growth of microbial was the $\mathrm{IC}_{50}$ of that sample.

\section{Results and Discussion}

\section{Synthesis of the DATPM compounds}

All of the diamines were synthesized by the Baeyer condensation of substituted aldehydes and aniline in the presence of an acid catalyst (aniline hydrochloride) in excess of aniline under solvent free conditions. The protonation of aldehyde group by the proton provided by aniline hydrochloride facilitates the nucleophilic attack of amino activated para position of aniline. The ortho isomer, from the attack of ortho position of aniline, is also formed as byproduct. The reaction mixture was obtained as highly viscous material which was then tediously purified by recrystallization from ethanol/ benzene followed by column chromatography. The formation of this viscous solution is because of the mixture of product and byproduct in excess of aniline.

\begin{tabular}{|c|c|c|c|c|c|c|c|c|c|}
\hline \multirow[b]{2}{*}{ Entry } & \multirow[b]{2}{*}{ Structures } & \multirow[b]{2}{*}{$\mathrm{IC}_{50}(\mu \mathrm{M})$} & \multicolumn{2}{|c|}{ Binding Energy (kcal/mol) } & \multicolumn{2}{|c|}{ H-Bonding } & \multirow{2}{*}{$\begin{array}{l}\text { Hydrophobic } \\
\text { Interactions }\end{array}$} & \multirow{2}{*}{$\begin{array}{l}\text { Electrostatic } \\
\text { interaction }\end{array}$} & \multirow{2}{*}{$\begin{array}{c}\text { Polar } \\
\text { interaction }\end{array}$} \\
\hline & & & $\mathbf{s}$ & London dG & $\begin{array}{l}\text { Interacting } \\
\text { residues }\end{array}$ & Distance (A) & & & \\
\hline 1 & & & -13.3775 & -10.5158 & Gln 730 & 1.41 & & $\begin{array}{l}\text { Gln } 729 \\
\text { Lys } 90\end{array}$ & Gln86 \\
\hline 2 & & & -11.9687 & -10.7363 & $\begin{array}{l}\text { Asn-712 } \\
\text { Thr-726 }\end{array}$ & $\begin{array}{l}1.55 \\
1.75\end{array}$ & & $\begin{array}{l}\text { Lys } 90 \\
\text { Glu729 }\end{array}$ & Gln 86 \\
\hline 3 & & & -11.8013 & -10.3447 & Glu86 & 1.62 & Met94 & $\begin{array}{c}\text { Gln86 } \\
\text { Asn372 }\end{array}$ & $\begin{array}{l}\text { Glu729 } \\
\text { Lys90 }\end{array}$ \\
\hline 4 & $\mathrm{H}_{2} \mathrm{~N}-\mathbb{C}$ & & -12.8138 & -9.4370 & Thr726 & 1.43 & & $\begin{array}{c}\text { Glu89 } \\
\text { Glu729 }\end{array}$ & Ser85 GIn86 \\
\hline 5 & $\mathrm{H}_{2} \mathrm{~N}-\langle\rangle$ & & -13.0787 & -10.0690 & $\begin{array}{l}\text { Thr-726 } \\
\text { Glu89 }\end{array}$ & $\begin{array}{l}1.73 \\
1.45\end{array}$ & $\begin{array}{l}\text { Met } 94 \\
\text { Phy-89 }\end{array}$ & $\begin{array}{l}\text { Lys90 } \\
\text { Glu729 }\end{array}$ & $\begin{array}{c}\text { Gln-86 } \\
\text { Asn732 }\end{array}$ \\
\hline
\end{tabular}

Table 1: Molecular docking studies of synthesized compounds against 1KKa (PDB code: 3BRT). 


\section{Molecular docking studies of the synthesized diamines}

The best docking poses of all 7 selected compounds produce results in which all of them form a single cluster inside the active side cleft of receptor as obvious from Figure 1. The compounds under observation have higher binding affinity with the receptors, in the narrow range of $(\mathrm{BE}=-13.38$ to $-11.80 \mathrm{kcal} / \mathrm{mol}$ : London $\mathrm{dG}=-10.73$ to $-9.9 .43 \mathrm{kcal} / \mathrm{mol}$ ). All the ligands formed strong hydrogen bonding with the key residues such as Gln 730, Asn-712, Thr-726, Glu-86, Glu 89 except ligand 7. Ligand 7 found to stabilize itself inside the pocket by tremendous other interactions with the key residues of the protein. The most prominent role is played by the $\mathrm{NH}_{2}$ group at phenyl ring as this $\mathrm{NH}_{2}$ formed strong. Both the $\mathrm{NH}_{2}$ groups at phenyl rings formed Hydrogen bonding in case of ligand 2, 5 and 6. Hydrogen bonding with the key residues inside the pocket is thought to be strong determinant for binding of ligand with the active residues. It is assumed that the rigidity of the structures which rendered them planer is also the major factor in determining the orientation patron and docking pose of the ligand inside the pocket, which in turn lead the compounds to attain the docking poses and orientate themselves in a fashion to form strong hydrogen bonding therefore the $2^{\text {nd }}$ major factor for the higher binding affinity may be attributed to the greater number of hydrogen bonds between ligand and protein.

Figure 2 depicts the preferred docked orientation of ligand 1 and 5 in the binding cavity of protein. No arene-arene and arene- $\mathrm{H}$ interaction is observed in case of all 7 compounds however, the compounds 3, 5 and 7 showed hydrophobic interaction with the Meth-94, compound 7 also exhibited hydrophobic interaction with Phe- 89 , Phe- 89 only found interacting with the ligand 7 . This phenyl ring is also involved in hydrophobic interactions with protein residues Met-94. The compound under observation corresponds to the binding energy and London $\mathrm{dG}$ values of -10.70 and $-9.50 \mathrm{kcal} / \mathrm{mol}$, respectively. The tremendous number of interactions with active site residues coupled with favorable binding energy proclaim that this compound may serve as an effective surrogate for the anticancer drugs. Another characteristic feature that discriminates the binding mode of 7 from rest of the 6 ligands lies in that

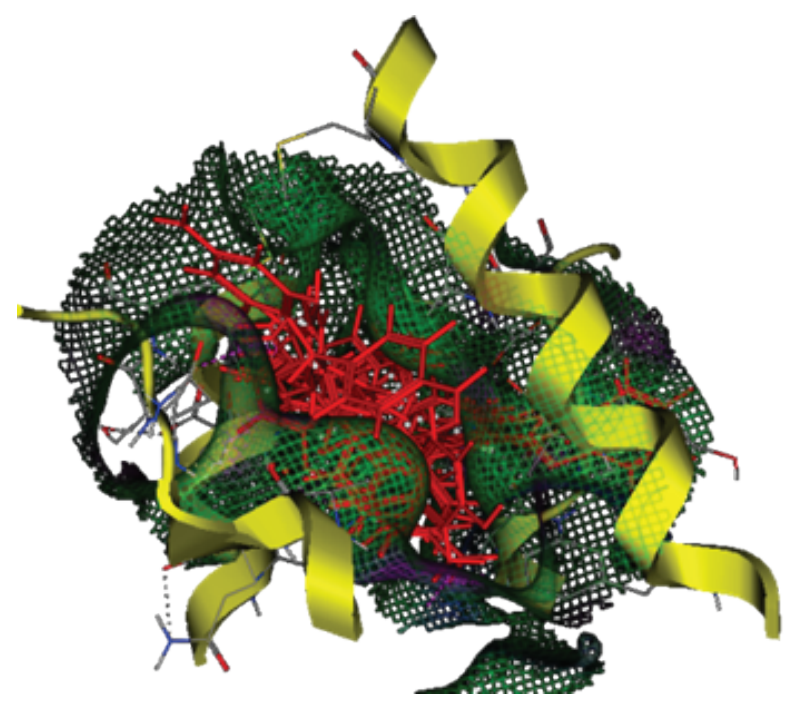

Figure 1: Superimposition of top ranked (on the bases of BE) docked poses inside the pocket.
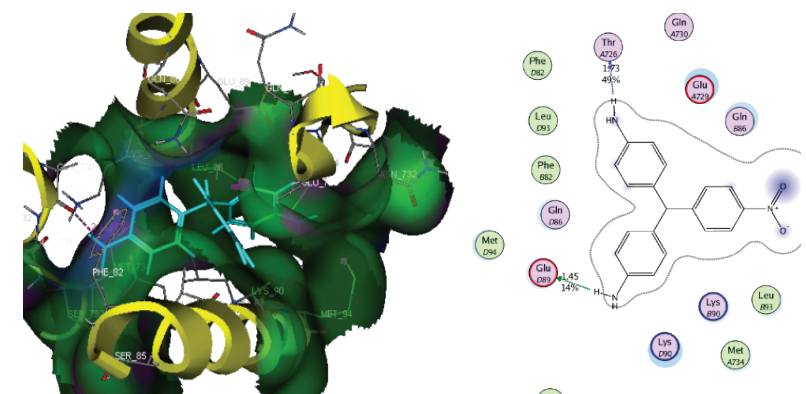

Figure 2: 3-D interaction of best docking pose of ligand 1, and 2D interaction of ligand 5.

\begin{tabular}{|c|c|c|c|c|c|c|}
\hline & $\begin{array}{c}\text { No. of } \\
\text { rotatable } \\
\text { bonds }\end{array}$ & MW & HBA & HBA & TPSA & logP(o/w) \\
\hline 1 & 3.0000 & 290.3660 & 3.0000 & 3.0000 & 72.2700 & 3.9470 \\
\hline 2 & 3.0000 & 274.3670 & 2.0000 & 2.0000 & 52.0400 & 4.2550 \\
\hline 3 & 3.0000 & 308.8120 & 2.0000 & 2.0000 & 52.0400 & 4.8470 \\
\hline 4 & 4.0000 & 304.3930 & 3.0000 & 2.0000 & 61.2700 & 4.2110 \\
\hline 5 & 4.0000 & 319.3640 & 5.0000 & 2.0000 & 97.8600 & 4.1900 \\
\hline
\end{tabular}

Table 2: Drug likeness of synthesized compounds.

\begin{tabular}{|c|c|c|}
\hline \multicolumn{3}{|c|}{ Diameter of growth inhibition zone in $\mathbf{~ m m}$ at $\mathbf{2 0} \mathbf{\mu g} /$ disc } \\
\hline Sample code & Clear Zone $(\mathbf{m m})$ & Bald Zone $(\mathbf{m m})$ \\
\hline 01 & --- & --- \\
\hline 02 & --- & $9 \pm 0.73$ \\
\hline 03 & --- & $10 \pm 0.98$ \\
\hline 04 & --- & --- \\
\hline 05 & --- & --- \\
\hline
\end{tabular}

Table 3: Protein kinase inhibition potential of various diamines agains Streptomyces 85E Strain.

the latter is stabilized in the active site by more nonpolar interactions although no Hydrogen bonding is observed.

\section{Lipinski's rule of five}

To determine the drug likeness of the synthesized compounds, Molecular descriptors were calculated for all the synthesized compounds by the ligand property calculation function of MOE (Table 2) and all of them were found to obey Lipinski's Ro5 cut-off limits, revealing the fact that synthesized compounds could be the further studied as potent anticancer drugs.

\section{Protein kinase inhibition assay}

Streptomyces $85 \mathrm{E}$ strain was used for the protein kinase inhibition assay. Moderate activity was observed by CDA-01 and DA-01, while other samples did not reveal any significant protein kinase inhibition activity. The maximum bald zone was exhibited by CDA- 01 i.e., 10 $\pm 0.98 \mathrm{~mm}$ followed by the DA-01 giving an inhibition bald zone of $9 \pm 0.73 \mathrm{~mm}$ (Table 3 ). The active samples that have the capability to inhibit the hyphae formation serve as protein kinases inhibitors because they don't allow the Streptomyces to form hyphae by inhibiting protein kinases and as a result bald zone appears. Uncontrollable and deregulated phosphorylation leads to the development of cancer. There is a need to explore the physiological role of protein kinases as 
protein kinase inhibitors can directly and quickly be used to arrest the kinase activity endogenously in normal cells and tissues, as well as in transformed cell lines [29].

\section{Conclusions}

Five diamines were synthesized and purified successfully. The analyses of binding mode of the docked poses supported the fact that all the five compounds could be effective anticancer drugs and assumed to be active in anticancer assays.

\section{Acknowledgements}

AHS is thankful to Higher Education Commission Pakistan for indigenous Scholarship for PhD. Department of Pharmacy is also acknowledged for carrying out the enzyme inhibition assays.

\section{References}

1. Yamato M, Hashigaki K, Yasumoto Y, Sakai J, Luduena RF, et al. (1987) Synthesis and antitumor activity of tropolone derivatives. 6. Structure-activity relationships of antitumor-active tropolone and 8-hydroxyquinoline derivatives. Journal of Medicinal Chemistry 30: 1897-1900.

2. Dothager RS, Putt KS, Allen BJ, Leslie BJ, Nesterenko V, et al. (2005) Synthesis and Identification of Small Molecules that Potently Induce Apoptosis in Melanoma Cells through G1 Cell Cycle Arrest. Journal of the American Chemical Society 127: 8686-8696

3. Benzaquen LR, Brugnara C, Byers HR, Gattoni-Celli S, Halperin JA (1995) Clotrimazole inhibits cell proliferation in vitro and in vivo. Nature medicine 1 : 534-540.

4. Khalid MH, Tokunaga Y, Caputy AJ, Walters E (2005) Inhibition of tumor growth and prolonged survival of rats with intracranial gliomas following administration of clotrimazole. Journal of neurosurgery 103: 79-86.

5. Snajdrova L, Xu A, Narayanan N (1998) Clotrimazole, an antimycotic drug inhibits the sarcoplasmic reticulum calcium pump and contractile function in heart muscle. Journal of Biological Chemistry 273: 28032-28039.

6. Natarajan A, Fan YH, Chen H, Guo Y, lyasere J, et al. (2004) 3, 3-Diaryl-1, 3-dihydroindol-2-ones as antiproliferatives mediated by translation initiation inhibition. Journal of medicinal chemistry 47: 1882-1885.

7. Al-Qawasmeh RA, Lee Y, Cao MY, Gu X, Vassilakos A, et al. (2004) Triaryl methane derivatives as antiproliferative agents. Bioorganic \& Medicinal Chemistry Letters 14: 347-350.

8. Schnitzer RJ, Hawking F (1964) Experimental Chemotherapy. Vol. II. Chemotherapy of Bacterial Infections. Part I. Experimental Chemotherapy. Vol. II. Chemotherapy of Bacterial Infections.

9. Arthur HL, Ernst F (1956) New biologically active polycondensed triarylmethane derivatives and a process for their preparation.

10. Jorgensen WL (2004) The Many Roles of Computation in Drug Discovery. Science 303: 1813-1818.

11. Rao BG (2005) Recent developments in the design of specific matrix metalloproteinase inhibitors aided by structural and computational studies. Current pharmaceutical design 11: 295-322.

12. Moustakas DT, Lang PT, Pegg S, Pettersen E, Kuntz ID, et al. (2006) Development and validation of a modular, extensible docking program: DOCK 5. Journal of computer-aided molecular design 20: 601-619.

13. Morris GM, Goodsell DS, Huey R, Olson AJ (1996) Distributed automated docking of flexible ligands to proteins: parallel applications of AutoDock 2.4 Journal of computer-aided molecular design 10: 293-304.

14. Jabeen F, Panda SS, Kondratyuk TP, Park EJ, Pezzuto JM, et al. (2015) Synthesis, molecular docking and anticancer studies of peptides and isopeptides. Bioorganic \& Medicinal Chemistry Letters 25: 2980-2984.

15. Perveen F, Qureshi R, Ansari FL, Kalsoom S, Ahmed S (2011) Investigations of drug-DNA interactions using molecular docking, cyclic voltammetry and UVVis spectroscopy. Journal of Molecular Structure 1004: 67-73.
16. Guzman-Lucero D, Guzman J, Likhatchev D, Martinez-Palou R (2005) Microwave-assisted synthesis of 4,4'-diaminotriphenylmethanes. Tetrahedron Letters 46: 1119-1122.

17. Schnick RA (1988) The impetus to register new therapeutants for aquaculture. The Progressive Fish-Culturist 50: 190-196.

18. Ganin EV, Vang VD (2003) Host-Guest Complexes. Selective Reaction of Crown Ether Hosts with Triphenylmethane Derivatives. Russian Journal of General Chemistry 73: 1320-1321.

19. Ajaikumar S, Pandurangan A (2008) HPW and supported HPW catalyzed condensation of aromatic aldehydes with aniline: Synthesis of DATPM derivatives. Journal of Molecular Catalysis A: Chemical 286: 21-30.

20. Ramalingam H, Sowrirajalu B, Ganesan A, Muthusamy S (2004) Synthesis and characterisation of organosoluble polyimides containing the anisyl moiety. Polymer International 53: 1442-1447.

21. Alvaro M, García H, Sanjuán A, Esplá M (1998) Hydroxyalkylation of benzene derivatives by benzaldehyde in the presence of acid zeolites. Applied Catalysis A: General 175: 105-112

22. Khosropour AR, Esmaeilpoor K, Moradie (2006) A p-toluene sulfonic acidpromoted rapid and facile baeyer condensation with microwave irradiation under solvent-free conditions. Journal of the Iranian Chemical Society 3: 81-84.

23. Manning G, Whyte DB, Martinez R, Hunter T, Sudarsanam S (2002) The protein kinase complement of the human genome. Science 298: 1912-1934.

24. Dhanasekaran N, Reddy EP (1998) Signaling by dual specificity kinases. Oncogene 17: 1447-1455.

25. Yao G, Sebisubi FM, Voo LY, Ho CC, Tan GT, et al. (2011) Citrinin derivatives from the soil filamentous fungus Penicillium sp. H9318. Journal of the Brazilian Chemical Society 22: 1125-1129.

26. Chemical Computing Group Inc. Montreal, QC, Canada.

27. Rushe M, Silvian L, Bixler S, Chen LL, Cheung A, et al. (2008) Structure of a NEMO/IKK-associating domain reveals architecture of the interaction site. Structure 16: 798-808.

28. Halgren TA, Nachbar RB (1996) Merck molecular force field. IV. Conformational energies and geometries for MMFF94. Journal of Computational Chemistry 17 587-615.

29. Bain J, Plater L, Elliott M, Shpiro N, Hastie CJ, et al. (2007) The selectivity of protein kinase inhibitors: a further update. Biochemical Journal 408: 297-315. 